\title{
O USO DA GESTÃO DE DESIGN NO FORTALECIMENTO DA IDENTIDADE DE MARCA EM UMA EMPRESA
}

Use of Design Management on strengthening the brand identity for a company

\author{
AMBROSIO, Vanessa Constance I Mestranda em Design \\ Universidade Federal do Paraná \\ vaneconstance@gmail.com
}

\section{HEEMANN Adriano I Doutor em Engenharia Mecânica}

Universidade Federal do Paraná

adriano.heemann@gmail.com

\begin{abstract}
Resumo
O presente artigo trata de uma pesquisa realizada com 15 escolas brasileiras que possuem curso de graduação em design. Tendo em vista a importância do ecodesign para a minimização de impactos ambientais negativos advindos do atual modelo de produção e consumo, acredita-se que a inclusão da disciplina Ecodesign é fundamental para que os designers possam atuar de maneira

\section{Abstract}

The present article analyzes a survey of 15 Brazilian schools that have graduation course in design. Given the importance of ecodesign to minimize negative environmental impacts from the current model of production and consumption, it is believed that the inclusion of the discipline Ecodesign is essential for designers to act in a systemic approach in the market.
\end{abstract} sistêmica no mercado.

Palavras-Chave: design; ecodesign; matriz curricular.

Key-words: design; ecodesign; curriculum. 


\section{INTRODUC̣̃̃O}

Uma marca é o patrimônio mais valioso de uma instituição e para que se possa estabelecer o equilíbrio entre o que ela representa e seu entendimento de seus usuários, é necessário se valer do uso de elementos que associem o racional e o emocional, objetivando assim, sua confiança e eficácia.

Segundo Louro (2000, p. 27) na concepção holística, as marcas são vistas como objetos vivos que se relacionam com os consumidores, ou seja, a marca poderá ser, dessa forma, entendida como uma promessa de um compósito de atributos (reais versus ilusórios, racionais versus emocionais, tangíveis versus intangíveis) geradores de satisfação.

A fim de que uma marca possua qualidade em sua comunicação e transmita de fato seu significado e sua mensagem, é preciso que haja organização, diretrizes e pessoas imbuídas no gerenciamento da sua personalidade. Nesse sentido, os profissionais de design tornam-se fundamentais para desempenhar o papel de integradores da marca.

Para Mozota (2011, p. 97), o design é fundamental para alcançar a coerência de uma marca, pois reúne diversos elementos de performance, seja de seus produtos e/ou de suas mensagens de serviço, do marketing e da comunicação que o suportam, além do comportamento e do visual de seus empregados e, do mesmo modo, dos espaços que representam a empresa e suas atividades, sejam elas físicas ou digitais. Além disso, o design potencializa a identidade da empresa e tem o poder de determinar a identificação e a diferenciação dos aspectos visuais da empresa, criando e transformando sinais gráficos em meios eficientes para transmitir a sua política de comunicação, o que, em muitos casos, reflete na gestão de marca como uma ferramenta eficaz de marketing. Igualmente, o design tem a condição de vincular as partes ora já existentes ou as que sofreram alterações, modificado assim, a estrutura de significados e estabelecendo novas conexões com o novo. Assim, a diferenciação e a gestão da marca são reflexos desses novos significados, que por sua vez, são consolidados por meio da Gestão de Design

Ao longo dos anos, o design vem sendo utilizado não somente para as etapas projetuais no desenvolvimento de produtos e serviços, mas sim, fazendo parte do contexto estratégico e estrutural das empresas e organizações. Neumeier (2010, p. 14) comenta que

Para organizar sua empresa com vistas à agilidade, é necessário que ela desenvolva uma "mentalidade focada no design", que confere a habilidade de mobilizar o mais 
amplo leque de soluções para os problemas capciosos com que se deparam sua empresa, seu setor ou seu mundo.

No entanto, ainda há uma grande dificuldade quanto a sua utilização na estratégia das empresas e instituições em geral. Muitas ainda se encontram presas a crenças, tradições, que não mais refletem o contexto atual do que o cliente espera de sua conduta. Contudo, o pensamento focado no design está em franca expansão; aos que se conscientizaram a tempo de que o design não é somente um utilitário projetual de produtos e serviços, mas sim um instrumento poderoso de mudança, os resultados aparecem de modo eficaz e lucrativo (NEUMEIER, 2010, p. 62). Dessa maneira, paulatinamente, introduz-se uma nova ideologia e se estabelece condutas e comportamentos que refletem significativamente numa nova postura empresarial, mais voltada ao design e à sua função estratégica.

A Gestão de Design vem sendo paulatinamente disseminada no meio empresarial privado, com potencial de crescimento em função de suas características, de produtos e serviços desenvolvidos. Os programas de design, apoiados e sustentados por instituições de fomento, estimulam a introdução do design nos negócios das empresas, incentivando e contribuindo para que o empresariado agregue valor aos seus produtos e, consequentemente, às suas empresas.

Best (2011, p. 21) destaca que

Gerenciar o modo como design conecta os objetivos de negócios (estrategicamente e operacionalmente), com a experiência do cliente, e em seguida, comunicar o valor adicionado pelo design, é uma das principais funções da Gestão de Design. Do ponto de vista organizacional, o design dá suporte à comunicação, seja ela corporativa ou da marca, de modo visível e experiencial, conectando o funcionamento interno de uma organização (visão, valores, objetivos) para o mundo externo envolvendo as partes interessadas, os consumidores e os usuários. A identidade organizacional é o cerne da estratégia de design, da gestão da marca e da gestão da reputação.

Diante desse contexto problemático, emerge a relevância de um estudo que analise métricas para que a gestão da marca possa ser efetiva. Desse modo, seria possível utilizar de modo diligente a Gestão do Design para melhor disseminá-la e torna-la reconhecida. 
Assim, o presente estudo tem como objetivo geral a análise de métricas de Gestão de Design, que possam subsidiar a gestão de marca e sua identidade para uma empresa ou organização. Para o alcance do objetivo geral, são estabelecidos os seguintes objetivos específicos:

- Realizar fundamentação teórica que possa esclarecer o conceito de marca e sua identidade e gestão, assim como o conceito de Gestão de Design e suas consonâncias;

- Utilizar métricas (já validadas) de alguns autores que permitam aferir de modo analítico a percepção da marca ou da cultura de uma organização;

De acordo com Rodrigues (2007, p. 3), pesquisar significa procurar respostas para indagações propostas. Quando se refere à pesquisa científica, é realizada uma investigação concreta e planejada, desenvolvida e redigida com o rigor científico e utilizando as metodologias consagradas pela ciência. É uma atividade voltada para a solução de problemas, fazendo uso de processos científicos, de procedimentos sistemáticos, baseados no raciocínio lógico, que tem por objetivo encontrar soluções para os problemas propostos. Como a presente pesquisa tem uma finalidade aplicada, os conhecimentos adquiridos poderão ser utilizados para a aplicação prática voltada para a resolução de problemas concretos da situação investigada.

A pesquisa é composta por uma teoria que será defendida e discutida ao longo deste estudo, buscando, assim, o fenômeno a ser investigado. Martins $(2004$, p.16) destaca que o ponto de vista admitido para o estudo e proposições da investigação deve possibilitar explicações, discussões e interpretações singulares, portanto, distintas dos enfoques convencionais pelos quais o tema foi comumente tratado.

O perfil desse estudo pode ser definido como exploratória, uma vez que o problema será caracterizado, classificado e definido. É uma pesquisa bibliográfica, pois exige a recuperação do conhecimento científico já existente sobre o problema.

\section{REFERENCIAL TEÓRICO}

\section{Marca: o elemento essencial da identidade}

Kotler (2008, p. 175) descreve que a marca é capaz de incorporar tudo o que uma empresa quer representar em relação aos seus produtos e serviços, atuando como um conjunto de atributos, benefícios e crenças, além de sua 
visão, valores, personalidade, posicionamento e imagem. A função primordial da marca é justamente identificar quem fabrica ou quem vende um produto e, no sentido mais amplo da palavra, incluem-se os bens tangíveis, serviços, organizações, pessoas, lugares e ideias. Sua construção se inicia antecipando as necessidades do cliente através do entendimento dos principais atributos de seus produtos e serviços. O autor considera que a marca representa provavelmente o mais poderoso instrumento de comunicação, entretanto, poucas organizações conscientemente criam e usam uma identidade de marca (declaração de posicionamento, definição de categoria, nome de marca, etc.) para colocar seus produtos e serviços no mercado. (KOTLER, 2008, p. 147).

Wheeler (2012, p. 12) destaca que, devido a infinidade de opções de marcas, as empresas passam a buscar formas de estabelecer uma ligação emocional com os clientes, tornando-se insubstituíveis e mantendo uma relação duradoura.

Carneiro (2009, p. 51-52) descreve que a marca está intrinsicamente vinculada à sobrevivência e à sustentabilidade da organização como um todo, tornando-se vital para manifestar a estratégia daquela empresa, não se restringindo apenas ao ciclo de vida de um produto ou serviço. Portanto, a marca ocupa cada vez mais espaço nas dimensões estruturais e estratégicas da organização.

De acordo com o Manual de Gestão de Design (CENTRO PORTUGUÊS DE DESIGN, 1997, p. 124-125), a marca é o elemento fundamental de identidade. É mais estável que as imagens publicitárias, sendo o seu desgaste incomparavelmente menor. Fixa a identidade essencial e institui associações no sistema visual da empresa.

Segundo a mesma obra, os requisitos da marca podem ser funcionais, semânticos e formais. No que tange a funcionalidade, os aspectos envolvidos na marca se referem à sua legibilidade à grande velocidade, sua capacidade em ser memorizada, sua originalidade para se distinguir e sua versatilidade para ser utilizada em diversas condições de reprodução e cor. No quesito semântico, a marca deve valorizar a cadeia que a associa aos produtos da empresa, serviços e assim como a sua qualidade, além de atender à política de comunicação geral. No aspecto formal, a marca deve apresentar uma compatibilidade de estilo com a empresa, adaptação aos gostos atuais e qualidades estéticas.

Neumeier (2003, p.7-14) sustenta que uma marca não é somente um logo, uma identidade corporativa e muito menos um produto ou serviço; uma marca é a intuição que uma pessoa tem sobre um produto, serviço ou empresa. 
Esse pensamento de Neumeier corrobora com o de Mozota (2003, p.85) que descreve a marca como uma imagem mental, um conhecimento estruturado e uma série de associações que, sob o ponto de vista semiótico, é um sinal, uma maneira de "chamar" um produto ou serviço que possui múltiplos significados.

Nesse sentido, de acordo com Mozota (2003), é possível estabelecer que, qualquer identidade gráfica, pode ser posicionada numa matriz com dois eixos: a do significado gráfico e do significado emocional, no qual o símbolo atua como um vínculo. Consequentemente, segundo Gobé (2001, apud MOZOTA, 2003, p. 101), as imagens (símbolos) são mais facilmente memorizadas do que palavras (nome) (Figura 1).

Figura 1 - O símbolo como vínculo entre o significado gráfico e o significado emocional.

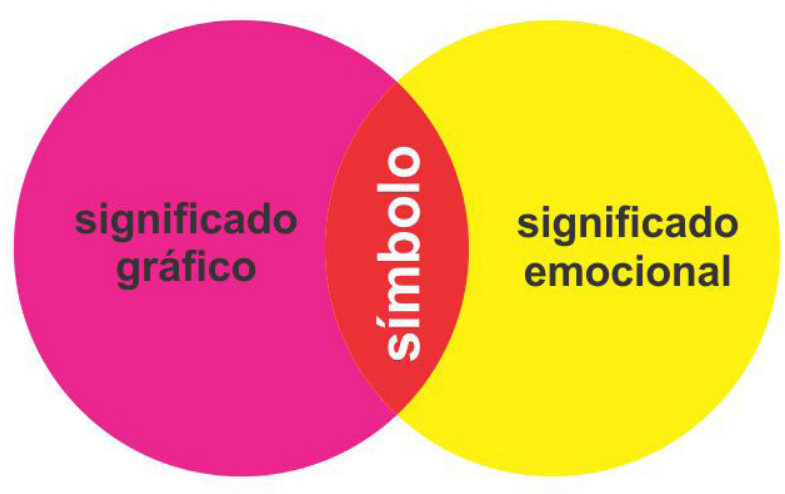

Fonte: Adaptado pela autora (GOBÉ, 2001 apud MOZOTA, 2003).

Seguindo de perto os esclarecimentos de Kotler (2008, p. 112), uma marca pode estar presente em inúmeras situações e de acordo com os propósitos daquela empresa. Usualmente, o primeiro passo é a criação de elementos que expressem graficamente o nome da instituição.

Como exemplo, pode-se aludir que um elemento gráfico como um logotipo é capaz de conectar o espaço entre as empresas e as pessoas, colaborando no desejo da definição e da comunicação da personalidade da empresa. No entendimento de Kotler (2008, p.112), um logotipo (ou logo) é a representação gráfica mais utilizada para apresentar uma marca numa organização, pois é o elemento que reúne o conjunto de experiências que colabora para a formação da percepção dessa marca na mente de seus consumidores. Um logotipo deve refletir os valores e as características corporativos, assim como estar contextualizado com a estratégia de marketing da organização. Também atua como um polarizador na identidade da marca, o que resulta no reconhecimento e na comunicação de modo simbólico, ao invés disso ser feito por uma 1 Gobé, Marc. Emotional Branding. Allworth Press, 2001. 
informação literal.

\section{Marca e identidade: diferença conceituais}

A conexão entre as marcas e os indivíduos é estabelecida quando a empresa desenvolve seu DNA, que nada mais é do que o meio mais apropriado para sua diferenciação. A singularidade e a autenticidade entre as redes de consumidores são construídas ao longo de sua existência e não surge de uma hora para outra. É uma tarefa árdua, mas que se torna fundamental na relação empresa-cliente.

Fascioni (2010, p.27) aponta a diferença entre identidade e marca: identidade define o que a empresa é, o seu todo; já a marca, representaria a parte boa, o que pode ser mostrado e valorizado. De acordo com a autora, a marca gráfica, o nome, a propaganda, seriam somente manifestações físicas da identidade de uma empresa, mas que também não garantiriam que ela seja exatamente como se apresenta. Enfim, uma empresa não muda sua essência se apenas alterar sua marca. Ela acrescenta

\section{[...] Se ela (a empresa) tem uma postura conservadora para tomar decisões, não é mudando a marca gráfica que ela vai se tornar inovadora. A representação gráfica é só uma forma de comunicar quem ela é e pode muito bem dizer bobagens que nada tem a ver com a identidade.}

Para representar graficamente a diferença entre identidade e marca, pode-se compará-las a um iceberg (Figura 2). Um iceberg é um bloco de gelo flutuante, que expõe somente $1 / 7$ de seu volume à superfície. Os outros 6/7 ficam submersos, o que funciona como um lastro para sua flutuação. Desse modo, a área superficial representa só parte visível de uma empresa, ou seja, sua marca e suas representações gráficas, enquanto que a área submersa, em sua maior parte, configura o cerne de sua identidade. 
Figura 2- Analogia entre as partes de um iceberg com os conceitos de marca e identidade

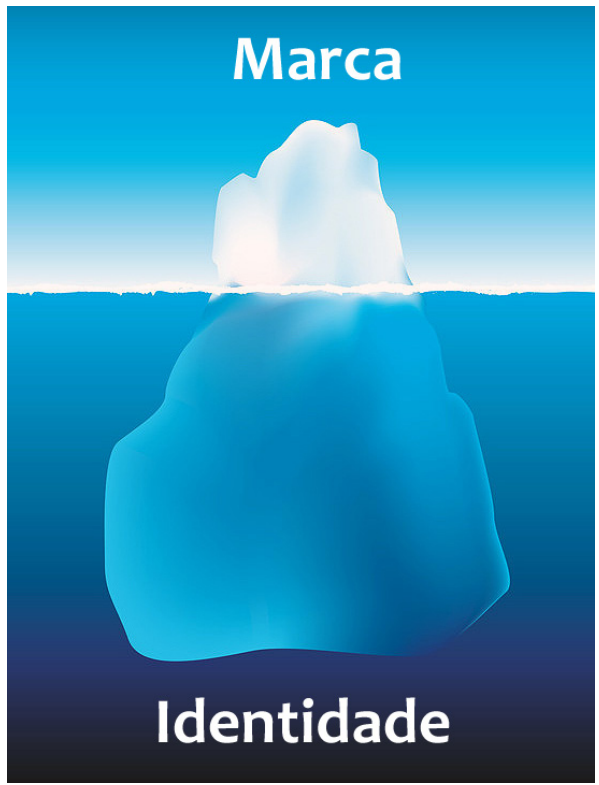

Fonte: A autora (2013).

No que se refere à autenticidade e diferenciação da marca, as empresas refletem a sua idoneidade proporcionando experiências verdadeiras e que sejam fiéis às suas intenções. Kotler (2010, p. 39) cita que as organizações

não devem tentar aparentar uma falsa realidade apenas na propaganda: caso o façam, perderão instantaneamente a credibilidade. No mundo horizontal dos consumidores, perder credibilidade significa perder toda a rede de possíveis compradores.

As experiências acumuladas na comunidade classificam as marcas e podem ou não comprometer a identidade da marca. Kotler (2010, p. 44) afirma que uma experiência ruim prejudicará a integridade da marca e destruirá sua imagem na comunidade, pois os usuários de mídia sociais sabem disso e os profissionais de marketing devem estar atentos ao seu uso. Esse fato pode ser percebido de modo bastante claro, pois, atualmente, as mídias sociais são um elo entre a empresa e o cliente.

\section{Requisitos e elementos constituintes da marca}

Kotler (2010, p. 41-42) identifica que o triângulo posicionamento, marca e diferenciação se complementa com os elementos definidores, como a identidade, a integridade e a imagem da marca (Figura 3). As suas três 
interações, o chamado Modelo dos 3 Is, são apresentadas a seguir:

- Identidade da marca: a identidade da marca deve assumir um posicionamento singular na mente dos consumidores para que seja eficientemente "ouvida" e notada. Uma marca pode ter uma identidade clara na mente dos clientes, porém, não ser suficientemente boa. $\mathrm{O}$ posicionamento também assegura que aquela marca é autêntica, advertindo seus consumidores contra outras empresas mal-intencionadas. A identidade da marca revela como a empresa deseja ser vista.

- Integridade da marca: a integridade da marca consolida o posicionamento e a diferenciação da marca. Diz respeito ao cumprimento das promessas, sua verossimilhança e a conquista da confiança do consumidor. Essa integridade é refletida pela diferenciação, que é o DNA da marca. Essa diferenciação, conectada com o posicionamento, irá proporcionar a boa imagem da marca. Então, pode-se afirmar que é onde a empresa deseja estar.

- Imagem da marca: a imagem da marca representa as necessidades emocionais dos consumidores, indo além das funcionalidades e características do produto ou serviço. A imagem da marca conquista a emoção das pessoas que consomem determinadas marca. A imagem da marca revela como a empresa é realmente vista.

Figura 3 - O modelo dos 3ls: Integridade, identidade e imagem da marca

\section{Integridade da marca}

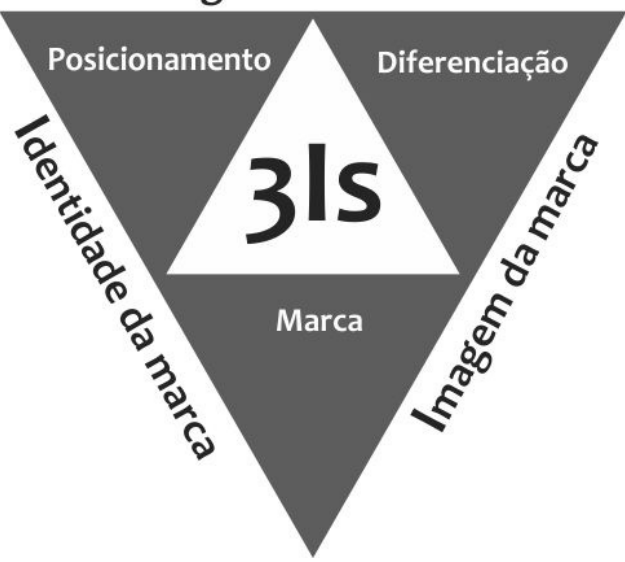

Fonte: adaptado de Kotler (2010).

\section{A Gestão de Design em conjunto com a Gestão de Marca}

A Gestão de Design desenvolve-se em três níveis: estratégico, tático e operacional. Best (2006, p. 25-26) destaca que num ambiente organizacional, os três níveis (Figura 4) devem estar plenamente engajados para o 
desenvolvimento de um projeto: no nível corporativo ou estratégico, envolvendo a visão, estratégia, política e missão; no nível da unidade de negócios ou tático, incluindo as táticas, os sistemas e os processos; e, finalmente, no nível operacional, a entrega de produtos e serviços tangíveis e 'tocáveis'.

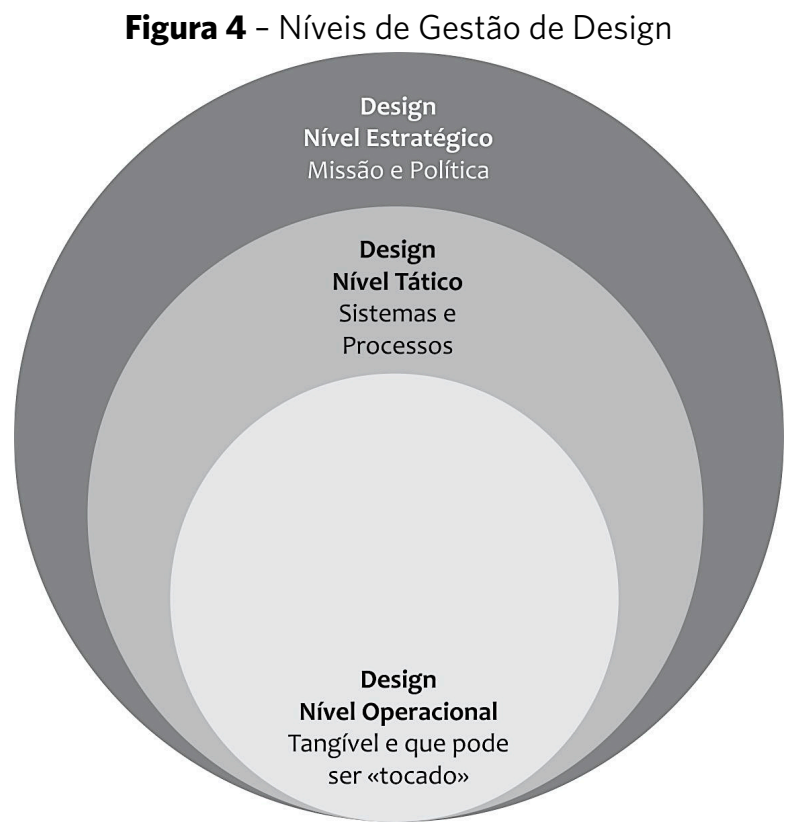

Fonte: Adaptado de Best (2006).

Martins e Merino (2011, p. 152) descreve os fatores que são considerados em todos os níveis da Gestão de Design, cada qual resultante de suas interações entre todos os setores das organizações. No nível estratégico, os fatores ambientais como: tendências de mercado, tendências de design, legislação, padrões; as manifestações do design (identidade corporativa, padrões de design corporativo, produtos, ambientes, comportamentos, comunicações), são tão influentes quanto os fatores internos, tais como: estratégias e controle do design corporativo, compreensão do design e desenvolvimento de habilidades para Gestão de Design, sua integração, centralização, responsabilidade pelo design, elaboração, além da introdução de sistemas para Gestão de Design, avaliação dos investimentos em design, seu impacto e sua contribuição para a atuação da organização. No que tange o nível tático atendem-se os recursos para o design (humanos, físicos, internos, externos); as habilidades para o design; core competencies²; treinamentos; descrição dos processos, normas e procedimentos para a Gestão de Design; localização, serviços e objetivos da equipe responsável pelo design. Finalmente, no nível operacional, considera-se a natureza dos processos e projetos de design; as propostas; o relacionamento 2 São capacidades essenciais ou competências distintivas que uma empresa incorpora desde seus fundadores até seus colaboradores e que não podem ser facilmente imitados e dão a empresa uma ou mais vantagens competitivas na criação e entrega de valor para os seus clientes em seu campo escolhido. 
entre gestão e equipe de design do projeto; seleção dos integrantes da equipe; documentação e sistemas de controle; implementação das soluções; avaliação dos projetos.

Martins e Merino (2011, p.26) aponta ainda que o campo de atuação do design transcende a criação de produtos e peças gráficas como elementos isolados, passando a ser parte de um sistema e consolidando-se como um processo de gestão. Ele (o design) possui a capacidade de alinhar aspectos tangíveis e intangíveis, como marca e produto físico; as necessidades de usuários e os atributos do produto, valor e custo; tecnologia e fator humano; ergonomia e produção; ergonomia e uso dos produtos, os materiais e as percepções.

Assim, quando há esse realinhamento de conduta, o papel do design passa a ser reconsiderado em sua forma de atuação nas empresas, contribuindo para o aumento da competitividade e da diferenciação de seus produtos e serviços. O profissional passa a focar nas soluções, não somente nos problemas.

Kotler (2008, p. 314-315) destaca que

[...] o design é uma síntese multidisciplinar enriquecida por corpos diversificados e complementares de conhecimento das ciências humanas, tecnologia e especializações materiais em estética e ciências da comunicação. [...] A meta de todo esse trabalho é alavancar o design como um agente de mudança e, ao mesmo tempo, promover relações mais sustentáveis entre pessoas, artefatos e ambientes.

O mesmo autor identifica graficamente a relação entre o alinhamento do Design Corporativo e a estratégia do Design de Produto (Figura 5). Quanto maior for a customização e a identidade do cliente, maior será a importância do design para o negócio. Porém, se apenas houver a preocupação com a identidade da empresa e as limitações da padronização assumida, menor é a relevância para o design. Assim, é possível perceber que, se a estratégia do design estiver voltada para as necessidades do cliente, maior será a vantagem competitiva para a empresa.

Figura 5 - Relevância do design em relação ao design corporativo e de produtos 


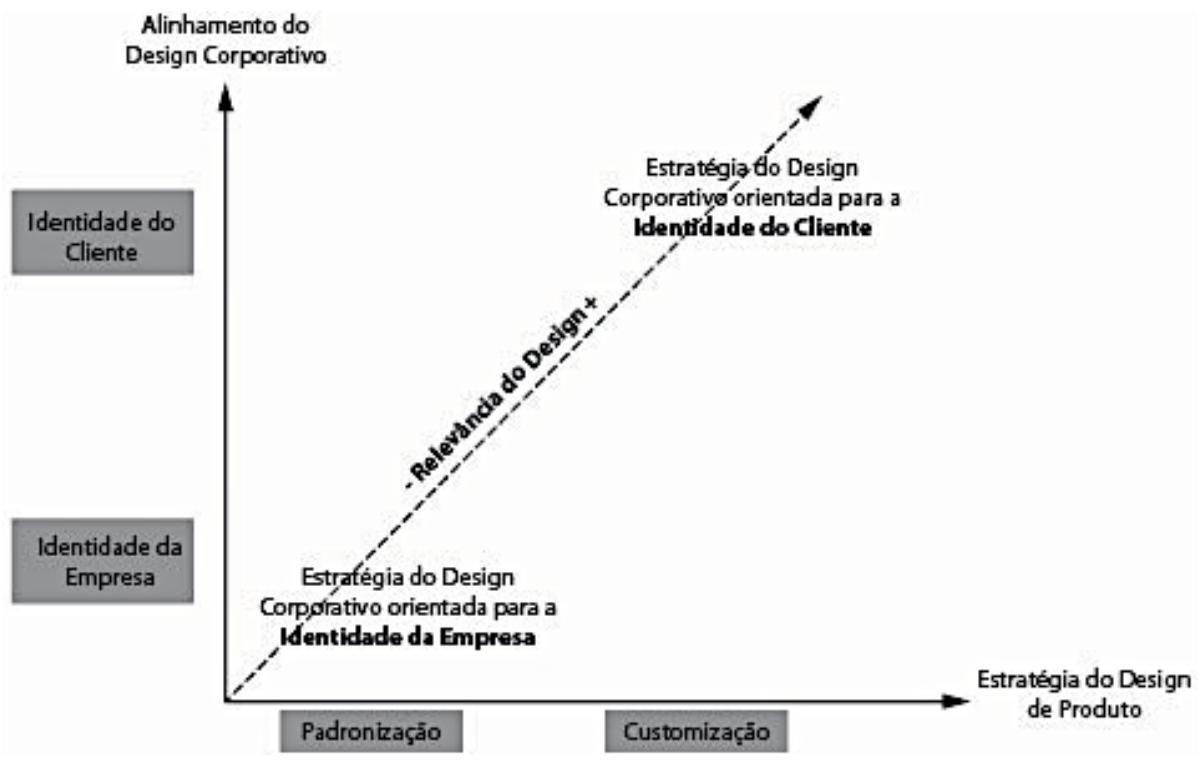

Fonte: Kotler (2008).

Martins e Merino (2011, p. 168) afirma que a empresa é uma personalidade que emite signos, portadores de significados, que informam e estão na origem das informações. A imagem da empresa é resultante global de seu passado, ações presentes e de sua política prospectiva. A autora prossegue, esclarecendo que à Gestão de Design é imputada a responsabilidade de diagnosticar e observar a estrutura existente numa empresa, revelando as diferenças, as heterogeneidades, os conflitos, a visão no contexto da mudança organizacional, assim como a construção da vantagem competitiva. Os valores que envolvem os níveis de atuação do design (Ação, Função e Visão) podem muito bem estruturar o contexto organizacional e alcançar a uniformidade de ações por meio de uma cadeia de valores voltadas para o design (Quadro 1).

Quadro 1 - A cadeia de valor do Design nas organizações e os três níveis da Gestão de Design

\begin{tabular}{|c|c|c|}
\hline Design AÇÃo & Design FUNÇÃO & Design VISÃO \\
\hline $\begin{array}{l}\text { Valor diferenciador do } \\
\text { design }\end{array}$ & $\begin{array}{l}\text { Valor coordenador do } \\
\text { design }\end{array}$ & $\begin{array}{l}\text { Valor transformador do } \\
\text { design }\end{array}$ \\
\hline $\begin{array}{l}\text { O design é uma compe- } \\
\text { tência econômica que age } \\
\text { sobre as principais ativida- } \\
\text { des da cadeia de valor }\end{array}$ & $\begin{array}{l}\text { O design é uma competên- } \\
\text { cia controladora que atua } \\
\text { sobre as atividades-suporte } \\
\text { de cadeia de valor }\end{array}$ & $\begin{array}{l}\text { O design é uma compe- } \\
\text { tência psicológica que } \\
\text { atua na cadeia de valor do } \\
\text { procedimento e a compre- } \\
\text { ensão pela empresa de seu } \\
\text { ambiente }\end{array}$ \\
\hline $\begin{array}{l}\text { Marketing } \\
\text { Produção } \\
\text { Comunicação }\end{array}$ & $\begin{array}{l}\text { Estrutura } \\
\text { Gestão da tecnologia } \\
\text { Gestão da inovação }\end{array}$ & $\begin{array}{l}\text { Estratégia } \\
\text { Gestão de saberes (ou do } \\
\text { conhecimento) }\end{array}$ \\
\hline $\begin{array}{c}\text { GESTÃO DE DESIGN OPERA- } \\
\text { CIONAL }\end{array}$ & $\begin{array}{c}\text { GESTÃO DE DESIGN FUN- } \\
\text { CIONAL (OU TÁTICO) }\end{array}$ & $\begin{array}{l}\text { GESTÃO DE DESIGN ES- } \\
\text { TRATÉGICO }\end{array}$ \\
\hline
\end{tabular}

Fonte: Adaptado de Martins e Merino (2011). 
O Manual de Gestão de Design (CENTRO PORTUGUÊS DE DESIGN, 1997, p. 36-37) destaca o papel do design na empresa, considerando dois aspectos:

- A sensibilidade da administração em relação a novos produtos e à imagem empresarial

Muitos diretores e executivos acreditam que para desenvolver novos produtos ou serviços e administrar a imagem corporativa de uma empresa não requer uma gestão especializada. Isso acontece porque acreditam que o design se envolve apenas com ações pontuais e, se houver uma situação de estabilidade, não há a necessidade de se preocupar e aprimorar a imagem da empresa, uma vez que, aparentemente, a mesma não corre riscos.

- Responsabilidade

A responsabilidade e a integração serão maiores quando as atividades de design são atribuídas a um departamento funcional da empresa, como um departamento técnico ou de marketing.

\section{METODOLOGIA}

De acordo com Louro (2000, p. 29), a medição do valor de uma marca poderá ser considerada um elemento determinante de avaliação da performance organizacional. Os conceitos, sistemas e esforços regulares de medição do desempenho da marca emergem como elementos orientadores da reflexão estratégica e da ação tática das empresas, essenciais para uma integração bem-sucedida de objetivos de curto e longo prazo. Desse modo, a seguir, utilizando-se das métricas existentes na literatura, é possível aferir, de modo analítico, o sucesso ou o fracasso da comunicação, a percepção da marca ou da cultura de uma organização.

\section{Design e Gestão de Marca: "produtos" (in)tangíveis e mensuráveis}

Uma empresa não poderá desenvolver novos e competitivos produtos se não houver uma organização adequada, correndo o risco de manter-se enrijecida e inativa, não gerando inovação.

O Manual de Gestão de Design (CENTRO PORTUGUÊS DE DESIGN, 1997, p. 116) descreve que, para que uma empresa possa diagnosticar como a projeção de sua identidade é percebida, é preciso que faça as seguintes considerações: 
- Temos realmente uma identidade própria de empresa?

- Há alguma diferença, em sentido negativo, entre o que somos e como nos veem? Sabemos como nos veem?

- Existe um programa de identidade coordenado?

- Oferecemos ao exterior uma "leitura" coerente e nítida da nossa imagem coordenada?

Ao responder essas questões, instituem-se os fatores que podem seguramente contribuir para identificar como a empresa é notadamente reconhecida e se realmente a mensagem que se quer transmitir é eficientemente transmitida.

Wheeler (2012, p.14) define que

a identidade de marca é tangível e faz um apelo para os sentidos, pois é possível vê-la, tocá-la, agarrá-la, observá-la se mover. A identidade de marca alimenta o reconhecimento, amplia a diferenciação e torna as grandes ideias e significados mais acessíveis, além de reunir elementos díspares que são unificados em sistemas integrados.

Já Best (2011, p.23-24) argumenta que o design pode ser considerado como intangível, devido à natureza integrativa e interdisciplinar, pois envolve as decisões concernentes aos processos e suas relações. É analisado no processo de decisão em como trazer os produtos e os serviços para o mercado (a ligação dos sistemas, os lugares, a entrega final do design e do gerenciamento da experiência do cliente). Do mesmo modo, atua na determinação em como gerar as relações entre as pessoas (os clientes, as consultorias de design, as partes interessadas e os usuários finais). $E$, igualmente, influi na decisão em como organizar as equipes, os processos e os procedimentos de qualquer projeto de design.

Martins e Merino (2011, p. 149) afirma que o gestor de design é responsável por todo o processo de criação de produtos, tangíveis e intangíveis. Em grandes empresas, possui a tarefa de supervisionar a eventual equipe envolvida no projeto, devendo adequar-se à complexidade de suas ações, que requerem uma visão da interferência da ferramenta, inicialmente, nas unidades de negócios e, depois, as integrando na estratégia global da empresa. 
Dentre as várias alavancas de mudança abordadas em sua obra, Neumeier (2010, p.135) elenca as métricas para tornar o intangível em tangível, fazendo uso da exatidão analítica, aferindo o sucesso ou o fracasso de um produto ou serviço, a comunicação, a percepção da marca ou da cultura daquela empresa. No quadro 2, destacam-se algumas delas:

Quadro 2 - Fatores que podem ser mensurados

\begin{tabular}{|c|c|}
\hline $\begin{array}{l}\text { Em relação ao } \\
\text { cliente } \\
\text { ou usuário }\end{array}$ & $\begin{array}{l}\text { Nível de interesse do usuário } \\
\text { Diferenciação em relação à concorrência } \\
\text { Classificação em relação às escolhas oferecidas pela concorrência } \\
\text { Nível de satisfação do cliente } \\
\text { Crescimento de comunidades de clientes } \\
\text { Grau de fidelidade do cliente } \\
\text { Lembrança espontânea Vs. Concorrência }\end{array}$ \\
\hline Em relação à marca & $\begin{array}{l}\text { Nível de consciência da marca } \\
\text { Nível de reconhecimento da marca } \\
\text { Valorização total da marca } \\
\text { Diferenciação da marca } \\
\text { Exclusividade das associações com a marca } \\
\text { Preferências por marcas }\end{array}$ \\
\hline $\begin{array}{l}\text { Em relação à } \\
\text { empresa e seus } \\
\text { colaboradores }\end{array}$ & $\begin{array}{l}\text { Nível de envolvimento do funcionário } \\
\text { Número de funcionários treinados para a marca } \\
\text { Número de designers internos } \\
\text { Satisfação do funcionário } \\
\text { Compreensão da missão e da visão } \\
\text { Contribuição do funcionário para a marca } \\
\text { Número de colaboradores }\end{array}$ \\
\hline $\begin{array}{l}\text { Em relação ao uso } \\
\text { de sites e/ou por- } \\
\text { tais de acesso }\end{array}$ & $\begin{array}{l}\text { Porcentagem de cliques no mouse } \\
\text { Número de cliques para a abertura de página } \\
\text { Formulários preenchidos on-line } \\
\text { Número de citações em blogs } \\
\text { Intensidade dos comentários feitos on-line }\end{array}$ \\
\hline $\begin{array}{l}\text { Em relação às } \\
\text { finanças }\end{array}$ & $\begin{array}{l}\text { Economia de custos com design } \\
\text { Receitas excedentes com design } \\
\text { Nível de gastos com design } \\
\text { Retorno sobre o investimento total em design } \\
\text { Economias com melhorias em processos } \\
\text { Geração de riquezas no interior de um domínio }\end{array}$ \\
\hline $\begin{array}{c}\text { Em relação ao } \\
\text { design }\end{array}$ & $\begin{array}{l}\text { Sentido cultural do conceito } \\
\text { Legibilidade das mensagens } \\
\text { Compreensão sobre elementos } \\
\text { Número de ideias novas apresentadas }\end{array}$ \\
\hline
\end{tabular}

Fonte: Adaptado de Neumeier (2010).

De acordo com as alavancas de Neumeier (2010, p. 134), é possível mensurar como a marca é assimilada e como o uso do design pode se tornar uma ferramenta essencial em seus pontos de contato. Assim, constata-se que em todo o contexto de uma empresaverifica-se como a marca é reconhecida e estabelecer meios para incrementar sua gestão. 
Kotler (2008, p. 185) cita as oito métricas qualitativas e quantitativas de ROBI (Return On Brand Investment ou Retorno sobre o Investimento na Marca) que Scott M. Davis ${ }^{3}$ delineou (Quadro 3). Essas métricas têm a função de medir qualitativa e quantitativamente a eficiência da marca e sua apreensão entre os clientes daquele produto ou serviço.

Quadro 3 - Métricas da marca segundo Scott A. Davis

\begin{tabular}{|c|c|c|c|}
\hline Métrica & Descrição & Qualitativa & Quantitativa \\
\hline $\begin{array}{l}\text { Conhecimento } \\
\text { da marca }\end{array}$ & $\begin{array}{l}\text { Fornece dados detalhados sobre } \\
\text { o nível de consciência, lembrança } \\
\text { e entendimento das marcas. }\end{array}$ & $\mathrm{X}$ & \\
\hline $\begin{array}{l}\text { Entendimento } \\
\text { do posicio- } \\
\text { namento da } \\
\text { marca }\end{array}$ & $\begin{array}{l}\text { Identifica o grau de entendimento } \\
\text { de diferentes segmentos de clien- } \\
\text { tes em relação ao posicionamen- } \\
\text { to da marca, bem como de seu } \\
\text { serviço ao cliente, contato pesso- } \\
\text { al, especialização e mensagens de } \\
\text { vendas focadas nos clientes. }\end{array}$ & $X$ & \\
\hline $\begin{array}{l}\text { Satisfação do } \\
\text { contrato pela } \\
\text { marca }\end{array}$ & $\begin{array}{l}\text { Determina se as marcas estão re- } \\
\text { almente cumprindo suas promes- } \\
\text { sas ao mercado. }\end{array}$ & $\mathrm{X}$ & $x$ \\
\hline $\begin{array}{l}\text { Reconhecimen- } \\
\text { to da personali- } \\
\text { dade da marca }\end{array}$ & $\begin{array}{l}\text { Estabelece a eficiência com a } \\
\text { qual a personalidade da marca é } \\
\text { comunicada a públicos internos } \\
\text { e externos, e o grau de enten- } \\
\text { dimento e lembrança entre o } \\
\text { público visado. }\end{array}$ & $\mathrm{X}$ & \\
\hline $\begin{array}{l}\text { Compras } \\
\text { motivadas pela } \\
\text { marca }\end{array}$ & $\begin{array}{l}\text { Avalia quantos novos clientes } \\
\text { são atraídos com as iniciativas da } \\
\text { gestão de portfolio de marcas e } \\
\text { traça igualmente um perfil desses } \\
\text { clientes. }\end{array}$ & & $X$ \\
\hline $\begin{array}{l}\text { Retenção e } \\
\text { fidelidade } \\
\text { de clientes } \\
\text { motivadas pela } \\
\text { marca }\end{array}$ & $\begin{array}{l}\text { Avalia o número de clientes per- } \\
\text { didos em função das estratégias } \\
\text { implementadas pelo portfólio de } \\
\text { marcas. }\end{array}$ & & $X$ \\
\hline $\begin{array}{l}\text { Penetração } \\
\text { e frequência } \\
\text { motivadas pela } \\
\text { marca }\end{array}$ & $\begin{array}{l}\text { Avalia o número de clientes que } \\
\text { estão comprando mais produtos } \\
\text { ou serviços como resultado da } \\
\text { gestão do portfólio de marcas. }\end{array}$ & & $x$ \\
\hline
\end{tabular}

3 Scott M. Davis é diretor de gestão no escritório Prophet Brand Strategy em Chicago, professor adjunto no Curso de Doutorado do Northwestern's Kellogg Graduate e contribuiu como editor para a revista Brandweek. 


\begin{tabular}{|l|l|c|c|}
\hline \multicolumn{1}{|c|}{ Métrica } & \multicolumn{1}{|c|}{ Descrição } & Qualitativa & Quantitativa \\
\hline $\begin{array}{l}\text { Valor finan- } \\
\text { ceiro da marca }\end{array}$ & $\begin{array}{l}\text { Mede o preço premium que as } \\
\text { marcas conseguem cobrar em } \\
\text { relação aos concorrentes e os } \\
\text { ganhos que podem ser atribuídos } \\
\text { à força da marca. }\end{array}$ & & $\mathrm{X}$ \\
\hline
\end{tabular}

Fonte: Adaptado de Kotler (2008).

As métricas qualitativas se referem ao conhecimento, entendimento do posicionamento e o reconhecimento da personalidade da marca. Também determinam se a marca cumpre, junto ao seu público, o que promete. Ou seja, essas métricas avaliam o grau de compreensão e o quanto o seu usuário entende sobre aquela marca.

Já as métricas quantitativas são determinadas pelos números absolutos da marca (compras, clientes, produtos e serviços) e valores cobrados, tanto pela própria empresa, quanto pelos concorrentes.

Do mesmo modo, ao considerar uma maneira de mensurar a marca, Kotler (2008, p. 317-318) elenca itens que devem ser atendidos para um diagnóstico profundo da marca, destacados da obra de Alina Wheeler (2012) (Quadro 4).

Quadro 4- Diagnóstico profundo da marca, apresentado por Kotler, segundo Alina Wheeler

\begin{tabular}{|c|c|}
\hline $\begin{array}{c}\text { Pesquisa e } \\
\text { Análise }\end{array}$ & $\begin{array}{l}\text { Criar uma equipe central, definir seus integrantes e comunicar o } \\
\text { projeto, objetivos e equipe de projeto a toda a empresa, marcar } \\
\text { reuniões, esclarecer a visão, estratégias e objetivos da liderança, } \\
\text { pesquisar as necessidades e percepções dos stakeholders }{ }^{5} \text {, rea- } \\
\text { lizar uma auditoria interna competitiva de tecnologia e aspectos } \\
\text { legais, entrevistar os principais gestores, e avaliar marcas existen- } \\
\text { tes da marca. }\end{array}$ \\
\hline $\begin{array}{l}\text { Estratégia da } \\
\text { marca }\end{array}$ & $\begin{array}{l}\text { Esclarecer a estratégia da marca, desenvolver uma plataforma de } \\
\text { posicionamento, criar atributos de marca, apresentar resumos } \\
\text { de documentos sobre a marca, criar uma estratégia de criação de } \\
\text { nome, avaliar as submarcas. }\end{array}$ \\
\hline $\begin{array}{l}\text { Conceito do } \\
\text { Design }\end{array}$ & $\begin{array}{l}\text { Visualizar o futuro, projetar a identidade da marca, finalizar a } \\
\text { arquitetura da marca, examinar a aplicabilidade, apresentar a } \\
\text { estratégia visual. }\end{array}$ \\
\hline \multicolumn{2}{|c|}{$\begin{array}{l}\text { Alina Wheeler é consultora de marca, designer e autora do livro 'Design de identidade } \\
\text { - guia essencial para toda a equipe de gestão de marca', que teve sua primeira edição no } \\
06 \text {. }\end{array}$} \\
\hline
\end{tabular}




\begin{tabular}{|c|l|}
\hline \multirow{2}{*}{$\begin{array}{c}\text { Expressões da } \\
\text { marca }\end{array}$} & $\begin{array}{l}\text { Finalizar a solução da identidade, dar início à proteção da marca } \\
\text { registrada, priorizar e projetar aplicações, projetar programa } \\
\text { de identidade, aplicar arquitetura da marca, avaliar a estratégia } \\
\text { de gestão, construir sinergia em volta da nova marca, desen- } \\
\text { volver estratégia e plano de lançamento, fazer o lançamento } \\
\text { inicial internamente, lançar a marca externamente, desenvolver } \\
\text { padrões e linhas de orientação, fortalecer as marcas principais, } \\
\text { dar sustentação ao legado, monitorar qualidade e desempenho } \\
\text { da marca. }\end{array}$ \\
\hline
\end{tabular}

Fonte: adaptado de Kotler (2008).

O diagnóstico proposto por Wheeler se mostra completo e detalhado, desde a pesquisa e análise realizada pela equipe de projeto, por meio de reuniões que esclarecem a visão, os objetivos, as necessidades e as percepções da marca, até a fase da estratégia e do posicionamento da marca, que culmina no conceito do seu design por meio de sua aplicabilidade e sua expressão.

\section{Os elementos e aplicações da marca: pontos de contato}

Outro modo de se aferir se a marca está sendo eficiente e atingindo seus objetivos previamente traçados é verificar suas aplicações e como seus pontos de contato estão sendo absorvidos e consumidos por seus clientes e usuários. Os pontos de contato são os itens visuais e físicos da marca que, se utilizados de forma adequada e coordenada, identificam e diferenciam o seu produto ou serviço. São eles: nome, logotipo (ou logo), cores, frase de efeito (slogan) e a histórica da marca. Inclui-se ainda personagens, música, sinais, embalagem.

A materialização da imagem de uma empresa não é só representada e manipulada pelos seus símbolos gráficos: todos os recursos de comunicação devem estar conectados, a fim de promover essa imagem. Abaixo, no Quadro 5, destacam-se os itens apresentados pelo Manual de Gestão do Design (CENTRO PORTUGUÊS DE DESIGN, 1997, p. 114).

Quadro 5 - Veículos de emissão da identidade e da marca de uma empresa

\begin{tabular}{|c|c|}
\hline \multirow{3}{*}{$\begin{array}{c}\text { Comunicação gráfica ou iden- } \\
\text { tidade visual }\end{array}$} & O logotipo e suas aplicações \\
\hline & Outros elementos visuais e gráficos \\
\hline & Meios audiovisuais \\
\hline \multirow{4}{*}{$\mathrm{O}$ produto } & As formas \\
\hline & As cores empresariais \\
\hline & Grafismo que acompanha o produto \\
\hline & Embalagem \\
\hline
\end{tabular}




\begin{tabular}{|c|l|}
\hline \multirow{4}{*}{\begin{tabular}{c} 
O meio onde se prestam os $\begin{array}{c}\text { serviços } \\
\text { s equipe humana }\end{array}$ \\
\cline { 2 - 2 }
\end{tabular}} & Escritórios \\
\cline { 2 - 2 } & Postos de venda \\
\hline \multirow{4}{*}{ Locais, delegações, exposições, stands, etc. } \\
\cline { 2 - 2 } & Relações públicas \\
\cline { 2 - 2 } & Dirigentes \\
\cline { 2 - 2 } & Empregados \\
\cline { 2 - 2 } & Vendedores \\
\hline
\end{tabular}

Fonte: Adaptado do Manual de Gestão de Design (CENTRO PORTUGUÊS DE DESIGN, 1997).

Do mesmo modo, os materiais impressos representam o mais versátil e frequente canal de divulgação e de comunicação entre a empresa e o consumidor para apresentar a sua marca. Outros meios como: propaganda, relações públicas, eventos especiais, marketing direto, itens promocionais, sinalizações e expositores, além de mídia popular e canais de comunicação pessoal, igualmente atuam como meios de propagação da marca. Porém, atualmente, os meios virtuais como: sites, blogs e redes sociais ganharam sua importância devido à sua facilidade e rapidez de acesso. As opções são inúmeras e algumas delas estão listadas no Quadro 6.

Quadro 7 - Veículos e canais de comunicação típicos

\begin{tabular}{|c|c|}
\hline \multicolumn{2}{|c|}{ PROPAGANDA } \\
\hline $\begin{array}{l}\text { Televisão } \\
\text { Rádio } \\
\text { Internet: banners em websites } \\
\text { Imprensa } \\
\text { Jornal } \\
\text { Revista } \\
\text { Anúncios na internet/websites } \\
\text { Anúncios no verso de ingressos e } \\
\text { receitas } \\
\text { Anúncios em salas de cinema utili- } \\
\text { zando cartazes e vídeos }\end{array}$ & $\begin{array}{l}\text { Publicidade externa } \\
\text { Outdoors } \\
\text { Anúncios em ônibus } \\
\text { Anúncios em paradas de ônibus } \\
\text { Metrôs } \\
\text { Táxis } \\
\text { Adesivos para carros e ônibus } \\
\text { Eventos esportivos } \\
\text { Quiosques } \\
\text { Cabines individuais de banheiros } \\
\text { Outdoors e sinalizações de aeroportos }\end{array}$ \\
\hline \multicolumn{2}{|c|}{ RELAÇÕES PÚBLICAS } \\
\hline $\begin{array}{l}\text { Histórias divulgadas no rádio e na } \\
\text { televisão } \\
\text { Artigos em jornais e revistas }\end{array}$ & $\begin{array}{l}\text { Colunas de opinião } \\
\text { Vídeos }\end{array}$ \\
\hline \multicolumn{2}{|c|}{ EVENTOS ESPECIAIS } \\
\hline $\begin{array}{l}\text { Encontros comunitários } \\
\text { Demonstrações/ Exibições }\end{array}$ & $\begin{array}{l}\text { Feiras } \\
\text { Passeios }\end{array}$ \\
\hline
\end{tabular}




\begin{tabular}{|c|c|}
\hline \multicolumn{2}{|c|}{ MARKETING DIRETO } \\
\hline $\begin{array}{l}\text { Correio } \\
\text { Internet/E-mail }\end{array}$ & $\begin{array}{l}\text { Telemarketing } \\
\text { Catálogos }\end{array}$ \\
\hline \multicolumn{2}{|c|}{ MATERIAIS IMPRESSOS } \\
\hline $\begin{array}{l}\text { Formulários } \\
\text { Folhetos } \\
\text { Boletins } \\
\text { Prospectos } \\
\text { Calendários }\end{array}$ & $\begin{array}{l}\text { Cartazes } \\
\text { Mensagens em envelopes } \\
\text { Livretos } \\
\text { Adesivos } \\
\text { Folheto para maçaneta de porta }\end{array}$ \\
\hline \multicolumn{2}{|c|}{ ITENS PROMOCIONAIS } \\
\hline $\begin{array}{l}\text { Vestuário: } \\
\text { Camisetas } \\
\text { Bonés } \\
\text { Coletes } \\
\text { Itens de natureza descartável: } \\
\text { Protetores para copos de café } \\
\text { Bótons } \\
\text { Balões } \\
\text { Adesivos }\end{array}$ & $\begin{array}{l}\text { Itens funcionais: } \\
\text { Chaveiros } \\
\text { Lanternas } \\
\text { Imãs de geladeira } \\
\text { Garrafas de água (Squeeze) } \\
\text { Canetas e lápis } \\
\text { Marcadores de livros } \\
\text { Capas de livros } \\
\text { Bloco de notas } \\
\text { Pastas de papelão } \\
\text { Porta-cartões } \\
\text { Sacolas }\end{array}$ \\
\hline \multicolumn{2}{|c|}{ SINALIZAÇÕES E EXPOSITORES } \\
\hline \multicolumn{2}{|c|}{$\begin{array}{l}\text { Placas de sinalização em estradas } \\
\text { Sinalização e cartazes em propriedades governamentais ou propriedades reguladas } \\
\text { pelo governo }\end{array}$} \\
\hline \multicolumn{2}{|c|}{ MÍDIA POPULAR } \\
\hline $\begin{array}{l}\text { Arte em local público } \\
\text { Músicas } \\
\text { Scripts de cinema, televisão e propa- } \\
\text { ganda em rádio }\end{array}$ & $\begin{array}{l}\text { Tiras e revistas de humor } \\
\text { Baralhos e outros jogos }\end{array}$ \\
\hline \multicolumn{2}{|c|}{ CANAIS DE COMUNICAÇÃO PESSOAL } \\
\hline $\begin{array}{l}\text { Apresentação e reuniões "cara-a- } \\
\text {-cara" } \\
\text { Oficinas, seminários, treinamentos }\end{array}$ & $\begin{array}{l}\text { Boca-a-boca } \\
\text { Divulgação por meio da web (comunicados, } \\
\text { broadcast) }\end{array}$ \\
\hline
\end{tabular}

Fonte: Adaptado de Kotler (2008, p.171). 
Corroborando Mozota (2003), a gestão de uma marca se dá por meio da diferenciação pelo design. Tal diferenciação vai além da identidade gráfica. Como analisado no item anterior, o desenvolvimento, o lançamento e o posicionamento de uma marca se apresentam como um dos modos mais eficientes de difundir o design em uma empresa. As funções da marca compreendem a criação de valor para os consumidores, informando sobre os atributos dos produtos; a geração de valor para a empresa, diferenciando o produto ou serviço, torna tangível o que é intangível.

Como também apresentado, os recursos da marca incluem credibilidade, legitimidade e afetividade. Assim, é possível argumentar que o design pode participar da valorização da marca tornando-a presente e perceptível em diferentes bases: embalagem, produto e propaganda. Em longo prazo, o design pode ser precursor de mercados diferentes. Ora, para a Gestão de Design, isso significa coerência em estética e forma, continuidade de uso de códigos gráficos e simbólicos e criação de novas emoções.

No âmbito da presente discussão, observa-se, assim como Aaaker (1991), que o reconhecimento do papel e do valor da marca como ativo das organizações obriga o desenvolvimento de estratégias de gestão e a potenciação do seu valor e que essa gestão deve ser feita balanceando a obtenção de resultados de curto prazo com o investimento na capacidade de geração de valor futuro por parte da marca. As métricas analisadas, portanto, inserem-se em um contexto de estudo e reflexões sobre a Gestão de Design.

\section{CONSIDERACÕES FINAIS}

Os designers podem atuar como colaboradores no processo de gestão da marca, uma vez que é preciso organizar toda a gama de mensagens que o público-alvo (clientes, consumidores atuais e potenciais) absorve no dia a dia, mensagens essas que são apresentadas em elementos gráficos, tais como: informativos, logotipos, marcas, impressos, entre outros.

Porém, para que de fato se alcance o sucesso nesse tipo de ação, o designer não deve trabalhar de maneira isolada: a alta administração deve estar plenamente envolvida, corroborando para que o designer desenvolva suas atividades com sucesso. Um dos principais preceitos para que a imagem de uma empresa exerça uma comunicação eficaz, é de se ater à coordenação e em sua resultante na integração das ações. Se essas ações se desencadearem de forma isolada em relação aos elementos de comunicação, resultará na incongruência e na dispersão destes elementos. (CENTRO PORTUGUÊS DE DESIGN, 1997, p. 
118).

Para implementar a colaboração em design na empresa, deve-se designar uma pessoa que crie diretrizes para o crescimento do valor da marca corporativa e de seus subprodutos (submarcas, sistemas de identidade, inputs para design, processos de inovação, programas de publicidade, comunicações, treinamento, etc.). Cabe a esse profissional articular e orientar as premissas para o aprendizado do design inserido na empresa, num trabalho de perseverança e dedicação, de modo a envolver todos nesse universo e conscientizar o quanto o design pode contribuir para todas as atividades.

\section{REFERÊNCIAS}

AAKER, David A. Managing Brand Equity. New York: Free Press, 1991.

BEST, Kathryn. Design management: managing design strategy, process and implementation. Lausanne, Switzerland: AVA Publishing, c2006.

BEST, Kathryn. What can Design Bring to Strategy? designing thinking as a tool for innovation and change. Rotterdam: Centre for Applied Research in Brand, Reputation and Design Management (CBRD) at Inholland University of Applied Research, 2011.

CARNEIRO, Levi. Marca corporativa: um universo em expansão. Belo Horizonte: Troiano Consultoria de Marca. Disponível em:<http:// brandinsights.com.br/arquivos/2009/08/Levi-Carneiro-MarcaCorporativa-um-universo-em-expsansao.pdf>. Acessado em: 19 jan. 2013.

FASCIONI, Ligia. DNA empresarial - identidade corporativa como referência estratégica. São Paulo: Integrare Editora, 2010.

KOTLER, Philip; PFOERTSCH, Waldemar. Gestão de marcas em mercados B2B. Porto Alegre: Bookman, 2008.

KOTLER, Philip. Marketing 3.0: as forças que estão definindo o novo marketing centrado no ser humano. Rio de Janeiro: Elsevier, c2010.

KOTLER, Philip; LEE, Nancy. Marketing no setor público: um guia para um desempenho mais eficaz. São Paulo: Bookman, 2008.

CENTRO PORTUGUÊS DE DESIGN. Manual de gestão de design. Porto, 
1997. (Coleção Design, Tecnologia e Gestão, 6).

MARTINS, Gilberto de Andrade. Estudo de caso: uma estratégia de pesquisa. 2. ed. São Paulo: Atlas, 2008.

MARTINS, Rosane Fonseca de Freitas. A Gestão de Design como estratégia organizacional: um modelo de integração do design em organizações. 2004. 202 f. Tese (Doutorado em Engenharia de Produção) -- Universidade Federal de Santa Catarina, Florianópolis, 2004.

MARTINS, Rosane Fonseca de Freitas; MERINO, Eugenio Andrés Diaz. Gestão de design como estratégia organizacional. Londrina: EDUEL, 2011.

NEUMEIER, Marty. A empresa orientada pelo design: como construir uma cultura de inovação permanente. Porto Alegre: Bookman, 2010.

NEUMEIER, Marty. The brand gap (o abismo da marca) - como construir a ponte entre a estratégia e o design. Porto Alegre: Bookman, 2008.

MOZOTA, Brigitte Borja de. Gestão do Design: usando design para construir valor de marca e inovação empresarial. Porto Alegre: Bookman, 2003.

RODRIGUES, William Costa. Metodologia Científica. Paracambi: FAETEC, IST, 2007. 40 slides, p\&b.

WHEELER, Alina. Design de identidade da marca - guia essencial para toda a equipe de gestão de marca. Porto Alegre: Bookman, 2012. 


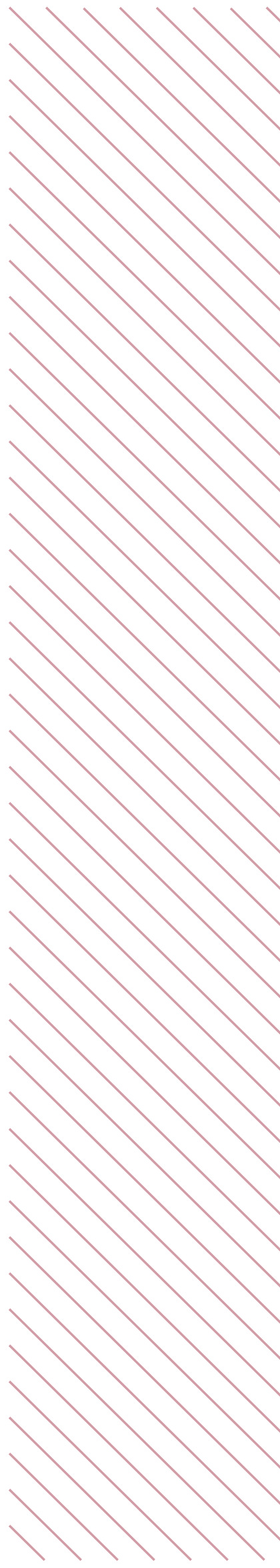

